\title{
EVOLUSI PEMIKIRAN MANAJEMEN STRATEGIK SEBELUM ERA 2000-an
}

\author{
Jati Waskito $^{1}$ dan Mugi Harsono ${ }^{2}$ \\ ${ }^{1}$ Fakultas Ekonomi dan Bisnis Universitas Muhammadiyah Surakarta \\ jw271@ums.ac.id \\ ${ }^{2}$ Fakutas Ekonomi dan Bisnis Universitas Sebelas Maret Surakarta \\ mugiharsono@yahoo.com
}

\begin{abstract}
By the 1960s, large companies moved from the emphasis on operations, budgeting and control areas to an emphasis on the complexity of evolving planning and environmental dynamism and the need for solutions to this situation from top managers demanding planning for the future and looking globally. This article aims to describe the evolution of strategic management thinking from the 1960s to 2000. Each decade has a dominant issue whose discussion is represented by a prominent strategist of his time. They are chosen because they lead to the concept of strategic thinking, tools, and certain techniques.
\end{abstract}

Keywords: Strategik, IO, RBV

\section{PENDAHULUAN}

Selama tahun 1950an, akademisi dan praktisi kurang memperhatikan konsep praktisnya strategi yang dikembangkan selama Perang Dunia II di arena militer. Dalam periode pasca perang ini, mengingat stabilitas pasar dan peningkatan permintaan, sebagian besar perusahaan di A.S. dan Eropa mulai berpikir terutama tentang sistem produksi yang efisien. Setelah itu, pada 1960-an, perusahaan besar bergerak dari penekanan pada area operasi, penganggaran dan pengendalian menjadi penekanan pada aspek kompleksitas perencanaan yang berkembang dan dinamisme lingkungan dan kebutuhan akan solusi untuk situasi ini dari manajer puncak perusahaan menuntut perencanaan masa depan dan melihat global. Akibatnya, kebanyakan sekolah bisnis pada saat itu membutuhkan "corporate policy" sebagai "batu loncatan" di semester akhir setiap kurikulum bisnis. Eksekutif puncak prihatin dangeram dengankebijakan generic jangka panjang perusahaan mereka. Ahli business policy mendorong pemikiran secara sistematis tentang strategi perusahaan(Guillén \& Mele, 2006).
Banyak penulis memperhatikan konsep strategi tapi gagal untuk menginvestigasi sejarah evolusinya dengan komprehensif. Kegagalan ini, yang berkaitan dengan pendekatan sejamannya, mengarah kepada sebuah kebingungan antara professional dan mahasiswa.Prinsip strategi yang mendasari didiskusikan oleh Homer, Euripides, dan banyak penulis lainnya.Konsep strategi di konteks militer atau politik masih terkenal sepanjang sejarah, dan telah didiskusikan oleh penulis terkenal seperti Shakespeare, Montesquieu, Kant, Mill, Hegel, Clausewitz, Liddell Hart, dan Tolstoy(Bracker, 1980).

Salah satu aplikasi strategi untuk bisnis yang pertama kali diketahui terjadi ketika Socrates menghibur Nichomachides, seorang militer Yunani yang kalah dalam pemilihan untuk posisi jendral oleh Antisthenes, pebisnis Yunani.Kebutuhan untuk konsep strategi terkait dengan bisnis semakin besar setelah Perang Dunia II, ketika bisnis berubah dari lingkungan yang relative stabil menjadi lingkungan yang kompetitif dan bergerak cepat(Bracker, 1980).

Bracker (1980) menambahkan bahwa penulis modern pertama yang menghubungkan 
konsep strategi ke bisnis adalah Von Neumann dan Morgenstern, dengan Teori Permainannya (Game Theory).Perbandingan konsep dari penulis modern ini ditunjukan oleh Hofer dan Schendel. Mereka menemukan bahwa di antara penulis, ada perbedaan besar dalam tiga area dasar: (1) luasnya konsep strategi bisnis, (2) komponen strateginya, jika ada, dan (3) keterlibatan proses strategi-formulasi. Artikel ini memaparkan evolusi pemikiran strategi beserta tokohnya, mulai dari era 1960an sd 2000an. Masing-masing era diwakili oleh tokoh pemikir yang paling berpengaruh beserta tema yang dominan, rasionalitas, konsep strategic, alat, dan teknik yang mereka suguhkan.

\section{Era 1960an (Mendifinisikan Strategi)}

Buah karya orisinil dariChandler (Wilson \& Toms, 2012)The Visible Hand (1977, Strategi dan Struktur, memposisikan konsep strategi sebagai fungsi bisnis yang terpisah dengan pemasaran, keuangan, dll. Strategi terdiri dari dasar penentuan tujuan jangka panjang perusahaan dan penerapan tindakan serta tindakan mengalokasikan sumber daya yang diperlukan. Untuk melaksanakan tujuan tersebut lahirlah konsep "struktur mengikuti strategi." Keputusan strategis kembali terlihat mengarah pada restrukturisasi perusahaan yang harus menghasilkan kinerja kompetitif yang superior.

Selama tahun 1960an, dua penulis lainnya membuat kontribusi signifikan untuk bidang baru ini. Salah satunya adalah Igor Ansoff, general manager Lockheed Electronics. Dalam buku strategi perusahaannya, dia berpendapat bahwa strategi digambarkan sebagai aturan untuk membuat keputusan yang ditentukan oleh ruang lingkup produk / pasar, pertumbuhan, keunggulan kompetitif dan sinergi. Konsep dan komponen strategi, bersama dengan gagasan penting yang diajukan Chandler, yang masih dijelaskan dalam buku teks manajemen strategis danmasih diterapkan oleh beberapa praktisi hari ini(Guillén \& Mele, 2006).

Sumbangan penting lainnya datang dari Kenneth Andrews dari Harvard Business School, baik dari hasil karya sendiri maupun dengan orang lain. Andrews menggarisbawahi pentingnya definisi bisnis sebagai bagian dari strategi, dan kebutuhan untuk menentukan misi perusahaan. Andrews mengembangkan alat analisis SWOT untuk memahami bagaimana sebuah lingkungan yang tidak pasti dengan memberikan label sebagai peluang dan ancaman (OT) yang harus disesuaikan dengan kekuatan dan kelemahan perusahaan (SW). Bekerja sama dengan para ilmuwan ini, Boston Consulting Group memperkenalkan konsep" experience curve", dan juga mengembangkan alat analisis pertama dari perencanaan portofolio, yang disebut "Growth / Share Matrix"(Gastón de los Reyes, 2011).

Tanggung jawab sosial dan nilai moral secara eksplisit dianggap oleh perintis konsep strategi di tahun 1960an. Igor Ansoff menyebut mereka dalam membahas pengaruh non-ekonomi yang mempengaruhi tujuan perusahaan. Dia menyebuttujuannon-ekonomi pribadi yang dia jelaskan termasuk filantropi, etika pribadi, tanggung jawab sosial, status sosial dan reputasi. Ansoffmenambahkan bahwa untuk memahami pengaruh dari aspekaspek ini, "prosedurnya adalah untuk memilih pengaruh non-ekonomi di dalam perusahaan yang memiliki pengaruh kuat terhadap tujuan ekonomi, dan kemudian untuk menilai sejauh mana atribut yang mempengaruhi dan prioritas pada daftar induk tujuan perusahaan "Ansoff (Hoskisson, Hitt, Wan, \& Yiu, 1999) often referred to as business policy, the current field of strategic management is strongly theory based, with substantial empir- ical research, and is eclectic in nature. This review of the development of the field and its current position examines the field $l u 2019$ s early develop- ment and the primary theoretical and methodological bases through its history. Early developments include Chandlerlu2019s (1962.

Pada era ini, banyak penulis yang memberikan kontribusi mereka untuk memberikan definisi manajemen strategik. 
Kronologi mereka dalam mendifinisikan (dapat dilihat pada tabel 1) menunjukan bahwa strategi bisnis memiliki karakteristik analisis lingkungan atau situasional digunakan untuk menentukan bentuk perusahaan dalam bidangnya, dan sumber daya perusahaan digunakan dengan cara yang benar untuk mencapai tujuan besarnya. Manajemen strategi memerlukan analisis lingkungan perusahaan internal dan eksternal untuk memaksimalkan penggunaan sumber daya dalam hubungannya dengan tujuan(Bracker, 1980).

Tabel 1. Kronologi Definisi Strategi Terbaru

\begin{tabular}{cl}
\hline Tahun & \multicolumn{1}{c}{ Kontributor dan Sumber } \\
\hline 1947 & $\begin{array}{l}\text { Von Neumann \& Morgenstern, } \\
\text { Theory of Games and Economic } \\
\text { Behavior [hal. 79-84] }\end{array}$ \\
$1954 \quad \begin{array}{l}\text { Drucker, The Practice of Manage- } \\
\text { ment [hal. 17] }\end{array}$ \\
& $\begin{array}{l}\text { Chandler, Strategy and Structure: } \\
\text { Chapters in the History of Ameri- } \\
\text { can Industrial Enterprise [hal. 13] }\end{array}$ \\
& $\begin{array}{l}\text { Ansoff, Corporate Strategy: An } \\
\text { Analytic Approach to Growth and } \\
\text { Expansion [hal. 118-121] } \\
\text { Cannon, Business Strategy and } \\
1968\end{array}$ \\
& $\begin{array}{l}\text { Policy [hal. 9] } \\
\text { Learned, Christenson, Andrews, } \\
\text { \& Guth, Business Policy: Text and } \\
\text { Cases [hal. 15] }\end{array}$
\end{tabular}

1971 Newman \&Logan,Strategy, Policy and Central Management [hal. 70]

Schendel \& Hatten, Business

1972 policy or strategic management, Academy of Management Proceedings [hal.4]

Uyterhoeven, Ackerman, \&

1973 Rosenblum, Strategy and Organization: Text and cases in General Management [hal. 9-10]

Ackoff, Redesigning the Future [hal. 29]

Paine \& Naumes, Strategy and

1975 Policy Formation: An Integrative Approach

McCarthy, Minichiello, \& Cur-

1975 ran, Business Policy and Strategy: Concept and Readings [hal. 9]

1976 Glueck, Business Policy: Strategy Formation and Management Action, edisi kedua [hal.3]

Strategi adalah serangkaian tindakan oleh sebuah perusahaan yang diputuskan terkait dengan situasi tertentu.

Strategi yaitu proses menganalisa situasi saat itu dan mengubahnya jika memungkinkan. Termasuk dalam hal ini adalah menemukan sumber daya milik seseorang atau bagaimana mereka seharusnya.

Strategi adalah penentu tujuan dasar jangka panjang sebuah bisnis, dan adopsi tindakan-tindakan dan alokasi sumber daya yang dibutuhkan untuk menyelesaikan tujuan-tujuannya.

Strategi adalah aturan untuk membuat keputusan yang ditentukan oleh lingkup produk/pasar, vektor pertumbuhan, keuntungan kompetitif, dan sinergi.

Strategi adalah keputusan tindakan terarah yang sangat dibutuhkan untuk mencapai tujuan perusahaan.

Strategi merupakan pola sasaran, tujuan, atau cita-cita dan kebijakan dan rencana utama untuk mencapai tujuan-tujuannya, yang disebutkan dengan cara tertentu untuk mendefinisikan di bisnis apa perusahaan tersebut atau menjadi apa dan jenis perusahaannya atau menjadi apa di kemudian.

Strategi adalah rencana-rencana yang memandangke depan yang mengantisipasi perubahan dan mengawali tindakan untuk mengambil manfaat kesempatan yang diintegrasikan ke dalam konsep atau misi perusahaan.

Strategi didefinisikan sebagai tujuan dan sasaran dasar organisasi, program utama tindakan yang dipilih untuk mencapai tujuan dan sasarannya, pola utama alokasi sumber daya untuk menghubungkan organisasi dengan lingkungannya.

Strategi memberikan arahan dan kepaduan bagi bisnisdan terdiri dari beberapa langkah: profil strategi, ramalan strategi, audit sumber daya, alternative strategi tereksplor, ujian untuk konsistensi, dan akhirnya pilihan strategi.

Strategi memperhatikan tujuan jangka-panjang dan cara untuk mencapainya yang mempengaruhi sistem keseluruhan.

Strategi adalah tindakanspesifik atau pola tindakanutama untuk mencapai tujuan perusahaan.

Strategi merupakan sebuah analisis lingkungan dan pemilihan alternative ekonomi yang cocok dengan sumber daya dan tujuanperusahaanpada resiko yang sepadan dengan keuntungan dan kelangsungan hidup yang ditawarkan alternatif.

Strategi merupakan sebuah rencana yang disatukan, luas, dan berintegrasi untuk memastikan bahwa tujuan dasar bisnisdapat dicapai. 


\begin{tabular}{cll}
\hline Tahun & \multicolumn{1}{c}{ Kontributor dan Sumber } & \multicolumn{1}{c}{ Definisi } \\
\hline 1977 & $\begin{array}{l}\text { McNichols, Policy Making and } \\
\text { Executive Action, edisi kelima } \\
\text { [hal. 9] }\end{array}$ & $\begin{array}{l}\text { Strategi berhubungan dengan pembentukan kebijakan: terdiri } \\
\text { dari serangkaian keputusan yang mencerminkan penentuan tu- } \\
\text { juan dasar bisnis dan penggunaan keahlian dan sumber daya } \\
\text { untuk mencapai tujuannya. }\end{array}$ \\
1979 & $\begin{array}{l}\text { Mintzberg, The Structuring of } \\
\text { Organizations [hal.25] }\end{array}$ & $\begin{array}{l}\text { Strategi adalah usaha mediasi antara organisasi dan lingkungan: } \\
\text { pola konsisten dalam keputusan organisasi untuk mengatasi } \\
\text { lingkungan. }\end{array}$ \\
& $\begin{array}{l}\text { Schendel \& Hofer, Strategic Man- } \\
\text { agement: A New View of Business } \\
\text { Policy and Planning [hal.516] }\end{array}$ & $\begin{array}{l}\text { Strategi memberikan isyarat arahan bagi organisasi untuk men- } \\
\text { capai tujuannya, pada saat yang sama merespon kesempatan } \\
\text { dan ancaman di lingkungannya. }\end{array}$ \\
\hline
\end{tabular}

Sumber: Bracker (1980)

Manajemen strategi adalah manajemen strategi; gambaran yang lebih luas mengaplikasikan konsep-konsep strategi dapat ditemukan pada pemikirannya Hofer bisnis yang telah dikembangkan dalam dan Schendel pada tahun 1979. Pada era inilah lingkaran akademik. Sehingga manajemen para pemikir strategi berusaha mencari definisi strategik melibatkan analisis lingkungan yang tepat untuk menterjemahkan konsep internal dan eksternal perusahaan untuk strategi, Mintzberg, Ahlstrand, \& Lampel, memaksimumkan manfaat sumberdaya yang (1998) menyebutkan sebagai era yang mana dimiliki perusahaan. Peryataan ini dapat para pemikir berupaya untuk mengidentifikasi dipertimbangkan sebagai denfinisi makro binatang yang belum jelas(amorf) sd. dari konsep strategi bisnis atau manajemen mengelompokkan paradigma strategi menjadi strategic.

Tabel 2 menunjukan rangkuman singkat pendekatan untuk mengoperasikan

Tabel 2

Pendekatan untuk Menerapkan Manajemen Strategi

\begin{tabular}{|c|c|c|}
\hline Tahun & Penulis & Penjelasan Hasil \\
\hline 1967 & Mueller & $\begin{array}{l}\text { Model regresi } 2 \text { SLS alokasi sumber daya strategis untuk menyelidiki } \\
\text { proses alokasi-anggaran pada sejumlah perusahaan. }\end{array}$ \\
\hline 1968 & $\begin{array}{l}\text { Boston Consulting } \\
\text { Group }\end{array}$ & $\begin{array}{l}\text { Model proses yang terkait dengan hubungan biaya/volume berbagai ma- } \\
\text { cam produk. Kesimpulan sejumlah strategi mengenai biaya, volume, } \\
\text { pasar saham, dan profitabilitas dikembangkan. }\end{array}$ \\
\hline 1972 & Elliot & $\begin{array}{l}\text { Analisis strategis yang menggunakan model persamaan simultan pada el- } \\
\text { emen besar kinerja perusahaan. }\end{array}$ \\
\hline 1973 & $\begin{array}{l}\text { Macintosh, Tsurumi, dan } \\
\text { Tsurumi }\end{array}$ & $\begin{array}{l}\text { Model regresi 2SLS yang menghubungkan pengepak daging bangsa } \\
\text { Kanada terbesar dengan model ekonomi bangsa Kanada dengan tujuan } \\
\text { analisis, persepsi lingkungan, dan menentukan tindakan strategi optimal. }\end{array}$ \\
\hline 1974 & $\begin{array}{l}\text { Schoeffler, Buzzell, dan } \\
\text { Heany }\end{array}$ & $\begin{array}{l}\text { Penelitian tentang hubungan strategi antara saham dan faktor lain dan } \\
\text { profitabilitas (PIMS) }\end{array}$ \\
\hline 1975 & $\begin{array}{l}\text { Buzzell, Gale, dan } \\
\text { Sultan }\end{array}$ & $\begin{array}{l}\text { Penelitian tentang hubungan strategi antara saham dan faktor lain dan } \\
\text { profitabilitas (PIMS) }\end{array}$ \\
\hline 1975 & Kirchhoff & $\begin{array}{l}\text { Analisis faktor internal yang berkontribusi terhadap pengembalian in- } \\
\text { vestasi; menggunakan model regresi stepwise SPSS. }\end{array}$ \\
\hline 1976 & $\begin{array}{l}\text { Schendel, Patton dan } \\
\text { Riggs }\end{array}$ & Model regresi strategi OLS pada strategi perubahan haluan perusahaan \\
\hline 1976 & Schendel dan Patton & $\begin{array}{l}\text { Model Regresi } 3 \text { SLS pada strategi perusahaan untuk mengatasi masalah } \\
\text { tujuan berganda dan untuk melihat pola kompleks strategi, operasi, dan } \\
\text { variabel lingkungan yang mempengaruhi pencapaian tujuan. }\end{array}$ \\
\hline
\end{tabular}




\begin{tabular}{cll}
\hline Tahun & \multicolumn{1}{c}{ Penulis } & \multicolumn{1}{c}{ Penjelasan Hasil } \\
\hline 1978 & Bass & $\begin{array}{l}\text { Model strategi yang diformulasikan untuk pelanggan yang tahan terhadap } \\
\text { level penetapan harga untuk setiap periode umur produk yang akan me- } \\
\text { maksimalkan potongan arus kas perusahaan. Menggabungkan model per- } \\
\text { mintaan Bass awal dengan kurva pengalaman Boston Consulting Group }\end{array}$ \\
\hline \multirow{2}{*}{1978} & $\begin{array}{l}\text { Hatten, Schendel, dan } \\
\text { Cooper }\end{array}$ & $\begin{array}{l}\text { Model regresi OLS industri Bir A.S. yang berhubungan dengan variabel } \\
\text { strategi (dapat dinkontrol) dan lingkungan (tidak dapat dikontrol) untuk } \\
\text { pengembalian perusahaan yang adil. }\end{array}$ \\
\hline
\end{tabular}

Sumber: Bracker, (1980)

Pada masa awal Yunani, konsep strategi bisnis telah berubah dari makro menjadi mikro dan kembali ke sudut pandang makro (lihat table 3)(Bracker, 1980). Pada saat itu para peneliti dan praktisi bisnis untuk beralih dari konsep pada sebuah konsolidasi terminology. Seperti sebuah konsolidasi yang akan memfasilitasi pengujian hipotesis empiris sebagai bagian untuk menentukan validasi atau menolak konstruk tradisional dan mengembangkan sebuah aplikasi yang bermanfaat terhadap lingkungan organisasi

Tabel 3

Sejarah Lingkup Manajemen Strategi

\begin{tabular}{|c|c|c|c|c|c|c|}
\hline \multirow[b]{2}{*}{ Periode } & \multicolumn{2}{|r|}{ Macro } & \multicolumn{2}{|c|}{ Micro } & \multicolumn{2}{|c|}{ Macro } \\
\hline & $\begin{array}{c}3000 \\
\text { SM }\end{array}$ & $\begin{array}{l}\text { Keruntuhan } \\
\text { Kota Yunani }\end{array}$ & $\begin{array}{l}\text { Kerajaan } \\
\text { Romawi }\end{array}$ & $\begin{array}{l}\text { Revolusi } \\
\text { Industri }\end{array}$ & $\begin{array}{c}\text { Paska Perang } \\
\text { Dunia II }\end{array}$ & $\begin{array}{c}\text { Masa } \\
\text { Depan }\end{array}$ \\
\hline $\begin{array}{l}\text { Dasar } \\
\text { Pemiki- } \\
\text { ran }\end{array}$ & $\begin{array}{l}\text { Pasar } n \\
\text { Organi } \\
\text { dan be } \\
\text { berhub }\end{array}$ & $\begin{array}{l}\text { ional } \\
\text { si kompleks } \\
\text { yang saling } \\
\text { gan }\end{array}$ & $\begin{array}{l}\text { - Lingkunga } \\
\text { - Ketersedia } \\
\text { terbatas } \\
\text { - Kurangnya } \\
\text { - Kurangnya } \\
\text { mengantis } \\
\text { - Lingkunga }\end{array}$ & $\begin{array}{l}\text { opolistik } \\
\text { nber daya tak } \\
\text { nasional } \\
\text { ampuan untuk } \\
\text { erubahan } \\
\text { g stabil }\end{array}$ & $\begin{array}{ll}\text { - Lingkungan } \\
\text { - Teknologi ba } \\
\text { - Kemampuan } \\
\text { mengantisipa } \\
\text { - } \text { Pasar nasiona } \\
\text { - Kemampuan } \\
\text { menghadapi } \\
\text { yang tidak pa }\end{array}$ & $\begin{array}{l}\text { dina- mis } \\
\text { eru-bahan } \\
\text { a depan }\end{array}$ \\
\hline $\begin{array}{l}\text { Definisi } \\
\text { Strategi }\end{array}$ & $\begin{array}{l}\text { Pengg } \\
\text { sumbe } \\
\text { menca }\end{array}$ & $\begin{array}{l}\text { aan efektif } \\
\text { aya untuk } \\
\text { i tujuan }\end{array}$ & $\begin{array}{l}\text { Penggunaan ef } \\
\text { untuk mencap }\end{array}$ & $\begin{array}{l}\text { an } \\
\text { an }\end{array}$ & $\begin{array}{l}\text { Analisis lingkung } \\
\text { internal dan ekste } \\
\text { memaksi-malkan } \\
\text { sumber daya terk } \\
\text { tujuan }\end{array}$ & $\begin{array}{l}\text { perusahaan } \\
\text { l untuk } \\
\text { ggunaan } \\
\text { dengan }\end{array}$ \\
\hline $\begin{array}{l}\text { Kontri- } \\
\text { butor } \\
\text { Utama }\end{array}$ & $\begin{array}{l}\text { Penulis } \\
\text { seperti } \\
\text { dan So }\end{array}$ & $\begin{array}{l}\text { wal Yunani } \\
\text { omer, Euripides, } \\
\text { ates }\end{array}$ & $\begin{array}{l}\text { Shakerspeare, } \\
\text { Mill, Hegel, C }\end{array}$ & $\begin{array}{l}\text { esquieu, Kant, } \\
\text { vitz, Tolstoy }\end{array}$ & $\begin{array}{l}\text { Von Meumann \& } \\
\text { Drucker, Chandle } \\
\text { Glueck, McNich } \\
\text { Miner, Mintzberg }\end{array}$ & $\begin{array}{l}\text { rgenstern, } \\
\text { nsoff, } \\
\text { Steiner, } \\
\text { ofer }\end{array}$ \\
\hline $\begin{array}{l}\text { Aplikasi } \\
\text { Strategi }\end{array}$ & $\begin{array}{l}\text { Bisnis, } \\
\text { Pemeri }\end{array}$ & $\begin{array}{l}\text { liliter, dan } \\
\text { ah }\end{array}$ & Pemerintah da & & $\begin{array}{l}\text { Bisnis, Militer, } \\
\text { Pemerintah }\end{array}$ & \\
\hline
\end{tabular}

Sumber: Bracker, (1980)

Era tahun 1970-an (Mengkonsepkan Manajemen Strategik)

Tahun 1970-an merupakan masa gejolak besar dan ada kebutuhan untuk pemikiran strategis. Inflasi dunia membuat upah dan nilai tukar mengambang volatile, dan pengendalian harga menjadi kenyataan. Dislokasi tahun 1970an menyebabkan munculnya perusahaan independen yang menawarkan panduan strategis pada saat ketika pemikiran dan alat strategis untuk analisis diminati secara khusus (Kuras, 2002). Konferensi besar pertama yang benar-benar ditujukan untuk subjek pengelolaan strategis diselenggarakan 
pada tahun 1977 di University of Pittsburgh. Hasil mencengangkandari konferensi ini, para periset mengubah nama lapangan dari perencanaan strategi menjadi manajemen strategis. Kontribusi dari penulis seperti Rumelt, Ansoff dan Mintzberg (Mintzberg et al., 1998) sangat penting untuk memahami periode ini, yang dapat digambarkan sebagai saat konseptualisasi manajemen strategis. Bidang manajemen strategis yang baru muncul menampilkan implementasi dan evaluasi sebagai komponen penting dari organisasi.

Para peneliti strategi dapat diidentifikasi dalam periode ini sebagai pendekatan konten strategi atau proses strategi. Salah satu karya paling berpengaruh dari penelitian konten, pada pertanyaan " apa strategi yang tepat". Hal ini dapat disebut sebagai kategorisasi strategi diversifikasi Rumelt. Di samping itu, ada penulis yang peduli dengan pemahaman proses penciptaan strategi, pada bagaimana untuk mengembangkan strategi. Di baris ini, Mintzberg et al., (1998) mengemukakan bahwa strategi muncul, bukan hanya pelaksanaan perencanaan.

Menggunakan analogi

buta,Mintzberg et al., (1998)mencoba untuk menggambarkan seekor gajah (ingat cerita di mana salah satu merasa ekornya pikir itu seperti tali, yang merasa kakinya pikir itu seperti pohon, yang merasa gading yang pikir itu seperti tombak, dll). Mereka mengidentifikasi 10 madzhab pemikiran yang berbeda, dan menjelaskan sejarah dan asal-usul, konsep dasar, aplikasi, kelebihan dan kekurangan, dan situasi di mana bahwa pendekatan untuk perencanaan strategis mungkin tepat.Mintzberg menguraikan apa yang mereka sebut ' strategi $5 \mathrm{P}$ ', yang benar-benar lima cara berpikir yang berbeda tentang karakteristik penting dari perencanaan strategis, yaitu: 1) Strategi sebagai rencana $\neg$ panduan untuk tindakan, jalur dari keadaan saat ini ke keadaan akhir masa depan yang diinginkan 2) Strategi sebagai pola $\neg$ “... yaitu, konsistensi perilaku dari waktu ke waktu. Sebuah perusahaan yang terus-menerus memasarkan produk yang paling mahal di industri mengejar apa yang dikenal sebagai strategi high-end, hanya sebagai orang yang selalu menerima yang paling menantang dari pekerjaan dapat digambarkan sebagai mengejar strategi berisiko tinggi. “ 3) Strategi sebagai posisi $\neg$ lokasi produk tertentu di pasar tertentu 4)Strategi sebagai perspektif $\neg$ strategi sebagai filosofi bisnis tertentu dalam hal berinteraksi dengan pelanggan, atau cara di mana barang atau jasa yang disediakan. 5) Strategi sebagai taktik, $\neg$ strategi adalah sarana untuk mendapatkan pangsa pasar melalui manuver tertentu, yang dirancang untuk mengecoh pesaing atau lawan.

Selanjutnya Mintzberg et al., (1998) mengelompokkan pemikiran strategi menjadi 10 madzhab dengan memberikanpenjelasan rinci dari masing-masing madzhab. Apabila disimpulkan menjadi madzhab preskriptif, yang mencoba untuk mengidentifikasi arah tindakan pada bagian dari perusahaan berdasarkan penilaian dari situasi saat ini dan bahwa lingkungan di mana ia beroperasi, dan madzhab deskriptif, yang hanya mencoba untuk memahami alasan historis mengapa keberadaan suatu perusahaan adalah pada titik tertentu dalam suatu waktu.

Sementara itu, Kenneth Andrews (Gastón de los Reyes, 2011) menggambarkan empat elemen strategi yang tidak terpisahkan: "1) kesempatan pasar, 2) kompetensi perusahaan dan sumber daya , 3) nilai dan aspirasi pribadi, dan 4) Pengakuan kewajiban kepada segmen masyarakat selain pemegang saham". Konsekuensinya, dalam mendesain sebuah strategi, seseorang harus menentukan apa yang bisa diraih(peluang), apa yang bisa dilakukan (resource), apa yang dianggap layak dilakukan (goal) dan apa yang harus dilakukan (responsibility).

Andrews bersikeras bahwa "Kita harus mengakui pada saat ini bahwa tidak ada cara untuk melepaskankeputusan menentukan strategi ekonomi yang paling masuk akal bagi perusahaan dari nilai pribadi mereka yang membuat pilihan". Bagi Andrews, perusahaan seharusnya mengikuti nilai manajer senior (nilai pribadi), tapi juga memperhatikan 
isu sosial, dan isu sosial dan moral apa yang dikatakan pemimpin (tanggung jawab sosial). Andrews mendifinisikan tanggung jawab sosial sebagai"sudut pandang berbagai pemimpin dan segmen masyarakat dan standar mereka sendiri tentang benar dan salah ".

Pada era ini pemikiran dialihkan oleh filsafat positivistik, yang secara hati-hati memisahkan fakta dari nilai-nilai, Simon (Guillén \& Mele, 2006)memilih untuk meninggalkan pertimbangan nilai dalam ilmu manajemen. Dia berpikir untuk urusan tujuan administrasi cukup untuk mempertimbangkan nilai-nilai yang dapat dicapai dan dapat dinilai.

Orang bisa sepakat bahwa sains itu lepas dari etika, tapi sains tidak sepenuhnya terlepas dari konteks filosofis dan manusia. Hari ini, perspektif positivisme itu mengurangi etika terhadap subjektivitas sedang dipertanyakan secara serius. Membatasi pengetahuan dengan menyesuaikan dengan apa adanya secara empiris dan harus dapat diverifikasi, seperti ditunjukkan oleh positivisme, menyebabkan seseorang mengabaikan bahwa banyak aspek realitas yangsecara langsung tidak dapat diamati dan diukur; hal ini menyebabkan seseorang hampir tidak bisa meragukan keberadaan mereka. Hal ini juga diterapkan pada konteks manajemen strategis (Godfrey \& Hill, 1995). Selain itu, ada juga keberatan filosofis terhadap akar metodologi positivisme. Jika semuanya harus diverifikasi, maka asas verifiability itu sendiri harus diverifikasi juga sampai saat ini asas verifiability itu sendiri belum dapat diverifikasi. Dengan kata lain, fondasi di mana rasionalitas ilmiah berada ternyata, secara paradoks, tidak ilmiah maupun rasional.

Mengurangi etika menjadi hanya nilai pada pribadi berarti etika tetap berada di luar rasionalitas keputusan. Karena kenyataan dipahami sebagai tidak memiliki nilai etis obyektif, tentu saja pandangan subjektif etika ini, sangat ekstrinsik strategi, telah lama mencegah etika menjadi kenyataan ditanggapi serius oleh ilmu manajemen.
Jadi, di bawah pengaruh positivisme, Prinsip etika normatif telah lama dikecualikan arus utama administrasi bisnis.

Karya fenomenal lain di era ini adalah tipologi strategi yang ditawarkan oleh Miles et al., (1978). Menurut mereka,kebanyakanproses organisasisecara dinamis menyesuaikan diri dengan perubahan lingkungan dan ketidakpastian-menjaga secara efektif keselarasan dengan lingkungan sambil mengelola yang saling ketergantunganinternalmerupakan hal yang sangat kompleks, meliputi keputusan dan segudang perilaku di beberapa tingkatan organisasi. Tetapi kompleksitas proses penyesuaian dapat ditembus: dengan mencari pola dalam perilaku organisasi, seseorang dapat menggambarkan dan bahkan memprediksi proses adaptasi organisasi. Maka perlunya kerangkauntuk menganalisis suatu model organisasi yang terpadu dan dinamis yang memperhitungkan keterkaitan antara strategi, struktur, dan proses.Secara khusus, kerangka ini memiliki dua elemen utama: (a) sebuah model proses adaptasi yang menentukan keputusan besar yang dibutuhkan oleh organisasi untuk menjaga keselarasan yang efektif dengan lingkungannya, dan (b) tipologi organisasi yang menggambarkan pola yang berbeda dariperilaku adaptif yang digunakan oleh organisasi dalam suatu industri tertentu atau pengelompokanlainnya.

Selanjutnya Miles et al., (1978) mengemukakan bahwa, jika seseorang menerima siklus adaptif sebagai hal yang valid, pertanyaannya akan menjadi: bagaimana organisasi bergerak melalui siklus? Artinya, apa yang dapat dilakukan oleh strategi organisasi dalam memecahkan masalah kewirausahaan, teknik, dan administrasimereka? Mereka mengkategorikan tiga jenis strategis organisasi: Defenders, Analyzer, dan Prospectors. Setiap jenis strategi memiliki keunikan tersendiri untuk berhubungan dengan pasar yang dipilih, dan masing-masing memiliki konfigurasi teknologi, struktur, dan proses tertentu yang konsisten dengan strategipasar. 
Era 1980-an (Pandangan Industrial Organization Economy - IO dari Strategi)

Dasawarsa 1980-an adalah periode di mana manajemen strategis kembali menawarkan sebuahkontribusi penting bagi dunia manajerial. Saat itu adalah masa ketenangan politik yang relatif di A.S., namun perubahan besar juga terjadi di luar negeri. Beberapa Elemen yang bisa menjelaskan dinamisme dan kompleksitas lingkungan dalam dekade ini antara lain liberalisasi politik Eropa Timur pada paruh kedua dekade ini, liberalisasi pasar di Asia dan Amerika Latin, atau pembentukan kelompok perdagangan di Eropa, bersamaan dengan tiruannya model bisnis Jepang oleh perusahaan terkemuka di seluruh dunia (Kuras, 2002).

Pada saat bersejarah ini, gagasan buku Michael Porter, strategi kompetitif pada tahun 1980 dankeunggulan kompetitif pada tahun 1985, memberikan panduan substantif kepada para analis, konsultan dan manajer. Ada yang berargumen bahwa buku-bukunya ini adalah legitimasi strategi sebagai disiplinakademisi. Secara khusus, "analisis industri lima kekuatan" dan "strategi generik" yang dijelaskan dalam buku-buku tersebut dianggap sebagai kontribusi pemikiran strategis paling berpengaruh saat itu(Barney, 1991).

Model Porter, yang mengimpor gagasan dari industriorganisasiekonomi, didasarkan pada logika performansi struktur-perilaku. Menurut model ini, kinerja perusahaan ditentukan oleh daya tarik struktur industri, yang bergantung pada lima kekuatan esensial: ancaman masuk, intensitas persaingan antar pesaing, tekanan dari produk pengganti, kekuatan tawar menawar pembeli, dan daya tawar pemasok. Karena itu, potensi keuntungan berhubungan langsung pada gabungan kekuatan kekuatan ini. Model ini membantu perilaku perusahaan dalam strukturindustri, dan perusahaan mungkin menggunakan tiga strategi generik utama (pilihan strategis) untuk mendapatkan keunggulan yang superior: kepemimpinan biaya keseluruhan, diferensiasi, dan fokus.
Model ini diadopsi dalam penelitian empiris, termasuk sebagai bagian dari buku teks strategi dan diimplementasikan di dunia bisnis. Sebenarnya, model ini menjadi awal era baru penelitian. Banyak penelitian yang dilakukan mengkaji efisiensistrategi generikselama tahun 1980an, sebagai kelanjutan pendekatandisiplin konten strategi. Sementara itu, penelitianproses strategi, berdasarkan ide Porter, juga mengembangkan konseptualisasi yang lebih canggihdan bidang penelitian menghubungkan dengan pendekatan berpengaruh lainnya. Misalnya penelitian yang dilakukan oleh Davis (1984) telah memberikan dukungan kepada tipologi Porter, bahwa perusahaan akan memiliki keunggulan kompetitif apabila mengimplementasikan salah satu dari tipologi strategi tersebut, atau kalau tidak maka dia memberi istilah stuck in the middle, bagi perusahaan yang gagal meraih keunggulan kompetitifnya.

Pemikiran manajemen strategis, pada periode ini, memulai berdialog dengan teori manajemen berpengaruh lainnya, seperti teori institusional (Meyer \& Rowan, 1977), pendekatan politik, atau pendekatan lingkungan dari populasi ekologi. Sedikitnya sepuluh madzhab pemikiran mengenai formasi strategi telah dijelaskan sampai dengan tahun 1980an, dan, meskipun beberapa orang mengkritik madzhab posisi Porter yang memiliki perspektifterlalu sempit, kebanyakan penulis dalam bidang kajian ini rata-rata setuju bahwa karyanya harus diperhitungkan sebagai telah memberikan kontribusi besar terhadap pemikiran strategis di dekade itu (Mintzberg et al., 1998). Selanjutnya Mintzberg et al., (1998)membedakan antara dua kategori dalam hal ini: madzhab Preskriptif, yang mencoba untuk mengidentifikasi arah tindakan pada bagian dari perusahaan berdasarkan penilaian dari situasi saat ini dan bahwa lingkungan di mana ia beroperasi, danmadzhab Deskriptif, yang hanya mencoba untuk memahami alasan historis mengapa keberadaan suatu perusahaan adalah pada titik tertentu dalam suatu waktu. 
Era 1990-an (Pandangan Strategi Berbasis Sumberdaya - RBV)

Teori Porter juga tetap dianggap penting selama dekade 1990-an, terutama konsep "nilai rantai ", yaitu sebuah alat untuk mengalisis nilai transaksi tahunan. Perusahaan konsultan seperti McKinsey memperluas konsep ini dengan mengembangkan model analisis sistem nilai. Dasawarsa baru ini ditandai dengan turbulensi lingkungan dengan tingkat daya saing yang lebih tinggi, Kewirausahaan dan inovasi. Saat itu di tahun 1990 internet mulai mengubah peranpelanggan dalam hubungan mereka dengan bisnis. Saat itu juga ditandai dengan kemunculan teknologi informasi yang canggih, dengan sistem penciptaan teknis yang kompleks untuk tujuan strategis internal dan eksternal. Saat itu, banyak diskusi strategi telah berlangsung sekitar membangun kompetensi untuk mendukung sistem semacam itu secara internal dan melalui aliansi dengan kunci Mitra (Kuras, 2002).

Porter(1991) berpandangan bahwa, agar perusahaan lebih fleksibel dalam merespon persaingan dan perubahaan pasar dengan cepat. Mereka harus memiliki tolak ukur secara terus menerus agar mencapai tingkat kinerja terbaik. Perusahaan juga harus melakukan outsourcing secara agresif untuk mencapai efisiensi, dan mereka harus memelihara beberapa kompetensi intinya agar tidak tertinggal dari para pesaingnya. Akar dari permasalahan hypercompetition atau kompetisi yang berlebihan adalah kesalahan dalam membedakan antara efektivitas operasional dengan strategi.

Diskontinyuitas teknologi dan ketidakpastian, yang terjadi pada tahun 1990an, menjelaskan perilaku perusahaan dan penciptaan berbagai produk atau cara pembuatan produk, diluar analisis eksternal lingkungan tempat perusahaan beroperasisebelumnya. Sedangkan pendekatan strategi terbengkalai, sebagian besar, pengaruh sumber daya organisasi pada manajemen strategis, sekarang sumber daya dan kapabilitasperusahaan tampaknya menjadi kuncielemen untuk menjelaskan kesuksesan mereka. Dalam konteks ini, sebuah perspektif baru diperkenalkan; Resource Based View (RBV)(Wernerfelt, 1984; J. Barney, 1991). Pendekatan ini menegaskansumber utama sebuah keunggulan persaingan berkelanjutan berada dalam pengembangan dan penggunaan sumber daya dan kemampuan perusahaan yang berharga. Argumen utamanya adalah jika sumber daya itu berharga, jarang dimiliki orang lain dan mahal untuk ditiru tanpa pengganti yang dekat, maka mereka bisa menjadi sumber keunggulan kompetitif yang berkelanjutan.

Perspektif ini melengkapi analisis kerangkaindustri. Tidak mungkin mengevaluasi daya tarik suatu industri secara independen dari sumber daya yang dibawa perusahaan ke industri tersebut (Barney, 1991). Sumber daya menjadi berharga karena kompleksitas sosial, elemen yang tidak tersedia dalam model yang lebih teknis seperti kontribusi Porter(Robert \& Grant, 1991). Sumber daya yang tidak dapat ditiru, seperti budaya dan reputasi, adalah tak berwujud, dan hasil interaksi kompleks. Mereka menjadi penting untuk menjelaskan keunggulan kompetitifsaat itu. Terlepas dari keterbatasan dalam mengukur sumber daya, beberapa penelitian empiris telah menguji secara statistik postulatdari RBV, yang mengkonfirmasikan pentingnya berbagi sumber daya antar bisnis, dan khususnya berhubungan dengan sumber daya tak berwujud dengan kinerja. Logika yang dibangun Barney sangat baik. Masing-masing kharakteristik sumberdaya diuraikan dengan jelas dan logis. Tidak hanya memberikan argument secara konseptual tetapi mengkaitkannya dengan strategic planning dan proses pengambilan keputusan perusahaan.

Selama tahun 1990an, bidang strategimemusatkan perhatiannya pada sumber daya yang paling mungkin mengarah pada keunggulan kompetitif. Organisasi harus dibentuk secara efektif untuk menyebarkan sumber daya yang berharga, langka, dan tak ada substitusinya. RBV (Barney, 1991; Wernerfelt, 1984) berpendapat bahwa 
kemampuan sebuah perusahaan untuk tampil lebih baik daripada pesaingnya tergantung pada interaksi unik manusia, sumber daya organisasi dan fisik dari waktu ke waktu. Pikiran strategis ini telah dilengkapi dengan aspek dinamis sumber daya "pendekatan kemampuan dinamis", terfokus pada driver dibalik penciptaan, evolusi dan rekombinasi sumber daya menjadi sumber baru keunggulan kompetitif(Teece, 2007). Kemampuan dinamis digambarkan sebagai rutinitas organisasi dan strategis dimana manajer memperoleh sumber daya, memodifikasinya, mengintegrasikan mereka, dan menggabungkan mereka untuk menciptakan nilai barustrategi.

RBV memberikan kontribusi besar bagi manajemen strategic yang mampu menjawab permasalahan yang tidak bisa dijawab dengan pendekatan IO. RBV mampu menjelaskan 1) kenapa perusahaan dalam satu industry yang sama tetapi memiliki kinerja yang berbeda? 2) bahwa perusahaan dapat meraih keunggulan kompetitif memalui sumberdaya internalnya 3) sumberdaya internal dapat memiliki keunggulan bersaing jika bernilai, langka, sulit ditiru, dan tak ada penggantinya 4) RBV dapat memperoleh first mover advantage, suatu keunggulan yang tak mungkin dimiliki dengan pendekatan IO.

Namun demikian, konsep RBV juga banyak dikritisi oleh peneliti yang lain seperti Priem \& Butler (2001): 1) RBV perlu memfikirkan definisi yang lebih jelas dan praktis pada konsep sumberdaya yang bernilai, unik, sulit ditiru, dan tidak ada penggantinya dalam riset empiris/praktis 2) RBV perlu mengembangkan lebih lanjut tentang pertanyaan "How". Bagaimana sumberdaya ini diperoleh dan berinteraksi satu dengan yang lainnya 3) RBV perlu mengembangkan lebih lanjut terhadap perubahan strategi sebagai akibat perubahan lingkungan 4) pertibangan yang lebih realistis - immobility, karena banyak aktivitas strategi yang memerlukan tingginya mobilitas sumberdaya.

Pada dekade ini juga muncul karya fenomenal "Strategic Intent"oleh Hamel dan Prahalad. Konsep ini merupakan evolusi dari ilmu manajemen hingga kemudian menjadi manajemen strategis dan fokus dalam melihat masa depan. Prahalad (1989)dengan percaya diri membahas masalah ini dengan memberikan sebuah model proses pengembangan strategikintentdan menghubungkannya dengan teori-teori lain yang baru dikembangkan seperti foresight, arsitektur strategis dan kompetensi inti untuk merancang masa depan. Dalam buku mereka yang berkompetisi untuk masa depan Hamel dan Prahalad membahas pentingnya maksud strategis dalam usaha organisasi untuk membangun masa depan mereka. Strategik intent berbeda dari perencanaan strategis dalam rencana strategis tersebut yang berfokus pada sarana sampai akhir, sementara strategik intent menentukan akhir dari ruang untuk proses perencanaan strategis yang fokus pada sarana (Hamel dan Prahalad, 1989). Strategik intent juga berbeda dari tujuan dan visi karena tujuan menjawab pertanyaan "apa yang harus dicapai" dan "kapan" sementara visi didefinisikan oleh serangkaian tujuan yang diinginkan. Strategik Intent tidak dibatasi oleh sumber daya dan viabilitas dari tujuan yang diinginkan, inilah yang membedakan konsep tersebut.

Keinginan para pemimpin untuk memberikan arahan memunculkan strategik intent yang didorong oleh kebutuhan untuk menetapkan jangka panjang. Tujuan, strategi untuk organisasi dan mempertahankan persaingan sehingga memberikan arahan jangka panjang kepada para manajer (Hamel dan Prahalad, 1994). Tujuannya adalah untuk melampaui perencanaan strategis sehingga memahami lembaga yang berorientasi masa depan dan memberi ruang bagi interpretasi dan improvisasi dalam menentukan bagaimana tujuan tersebut diwujudkan (Mburu \& Thuo, 2015). Dengan latarbelakang diatasjelas bahwa maksud strategis melampaui kepentingan pengembangan suatu rencana strategis, yang bekerja pada misi organisasi, vison dan tujuan. Ini adalah untuk membayangkan posisi kepemimpinan yang diinginkan dan menetapkan kriteria yang akan digunakan organisasi untuk memetakan kemajuannya 
(Hamel dan Prahalad 1989). Keinginan untuk menang dan stabil sepanjang waktu memotivasi para pemimpin untuk terlibat dalam tujuan strategis, membuat mereka melampaui hal yang dapat dibayangkan atau berpikir tidak terpikirkan untuk menciptakan komitmen terhadap masa depan organisasi, menetapkan prioritas yang kompetitif bagi organisasi, dan membantu membentuk inti perusahaan. Kompetensi untuk bersaing di masa depan yang diinginkan (Mburu \& Thuo, 2015).

\section{Era 2000 (Pandangan Baru pada Manajemen Strategik)}

Dekade ini adalah suatu masa dimana suatu hal yang pasti itu hanyalah ketidakpastian itu sendiri.Menurut Nonaka \& Lewin, (1994) salah satu sumber keunggulan kompetitif yang langgeng adalah pengetahuan. Saat pasar bergeser, teknologi berkembang dengan pesat, pesaing berlipat, dan produk menjadi usang hampir dalam semalam. Perusahaan yang sukses adalah mereka yang secara konsisten menciptakan yang pengetahuanbaru, menyebarkannya secara luas ke seluruh organisasi, dan dengan cepat mewujudkannya dalam teknologi dan produk baru. Kegiatan ini menjadikan perusahaan sebagai"knowledgecreating"yang ruh bisnisnya adalah inovasi yang berkelanjutan. Namun, terlepas dari semua pembicaraan tentang "kekuatan otak" dan "modal intelektual", beberapa manajer memahami sifat sebenarnya dari -knowledge-creating company- apalagi mengerti bagaimana mengelolanya. Inilah alasan mengapa mereka salah paham, apa itu pengetahuan dan apa yangperusahaan harus lakukan untuk memanfaatkannya.

Sementara itu Prahalad (2003) mengatakan bahwa pada decade ini dimulai dengan kabar baik: kemajuan dalam digitalisasi, bioteknologi dan material yang cerdas- masing-masing mewakili konvergensi beberapa teknologi diskrit - yang dapat meningkatkan peluang di berbagai industri. Diskontinuitas utama di lanskap kompetitif - deregulasi, konektivitas terjadi di media yang tak terbatas dan globalisasi - semakin mempercepat tren ini. Seiring berubahnya lingkungan persaingan dengan cepat, potensi inovasi menjadi lebih besar dari sebelumnya. Kabar buruknya: manajer berada di bawah tekanan yang luar biasa untuk menciptakan nilai dibawah kondisi persaingan yang sangat ketat, dan margin keuntungan menyusut. Resep tradisional seperti pengurangan biaya, reengineering dan outsourcing, tidak bisa mengatasi masalah tekanan margin. Kebutuhan untuk berinovasi adalahsebuah keniscayaan dari pada masa sebelumnya. Di dunia baru ini, penciptaan nilai melalui pertumbuhan yang menguntungkan hanya bisa datang dari inovasi. Namun konvergensi industri dan peran aktif konsumen dalam masyarakat yang semakin berjejaring mempertanyakan konsep dasar kita tentang nilai dan proses yang mengarah pada penciptaannya.

Menurut Pfeffer, Jeffrey dan Sutton (2000),pasar untuk pengetahuan bisnis berkembang pesat, karena perusahaan yang ingin meningkatkan kinerjanya menuangkan miliaran dolar ke dalam program pelatihan, konsultan dan pendidikan eksekutif. Mengapa, kemudian, ada begitu banyak celah antara apa yang perusahaan tahu harus mereka lakukan dan apa yang sebenarnya mereka lakukan? Mengapa begitu banyak perusahaan gagal menerapkan pengalaman dan wawasan yang telah mereka hasilkan dengan sangat sulit untuk diperoleh? Dalam bukunya The Knowing-Doing Gap: Bagaimana perusahaan pintar mengubah pengetahuan menjadi tindakan, para penulis menghadapi tantangan yang dihadapi perusahaan saat ini dalam mengubah pengetahuan menjadi tindakan produktif. Mereka mengidentifikasi penyebab 'The Knowing-Doing Gap' dan menjelaskan bagaimana menutupnya. Perusahaan yang mengubah pengetahuan menjadi tindakan menghindari 'smart talk trap.'Perusahaan yang bertindak berdasarkan pengetahuan mereka menghilangkan rasa takut, menghapuskan kompetisi internal yang merusak, mengukur hal-hal penting dan mendorong pemimpin yang memahami pekerjaan yang dilakukan 
orang di perusahaan mereka. Banyak contoh perusahaan yang telah mengatasi kesenjangan pengetahuan-tindakan ini disorot dalam buku ini. Studi kasus lainnya termasuk perusahaan yang mencoba, namun gagal, namun organisasi lain yang berhasil menghindari kesenjangan sejak awal.

Di dunia baru ini, menurut Prahalad (2003), penciptaan nilai melalui pertumbuhan yang menguntungkan hanya bisa datang dariinovasi. Namun konvergensi industri dan peran aktif konsumen dalammasyarakat yang semakin berjejaring mempertanyakan konsep dasar kita tentang nilaidan proses yang mengarah pada penciptaannya, termasuk alkimia inovasi. Para manajer menemukan bahwa tidak ada nilai atau inovasi yang bisa berhasil lagi dan dihasilkan secara berkelanjutan melalui fokus perusahaansentris, produk dan layanan prima. Diperlukan sudut pandang baru, yang memungkinkan pelanggan individual untuk melakukannya secara aktif menggabungkan pengalaman konsumsi mereka sendiri melalui personalisasi interaksi, sehingga menciptakan nilai unik bagi diri mereka sendiri. Tidak ada praktik terbaik untuk menggambarkan perspektif ini karena, memang, tidak ada satu perusahaan pun yang bisa digunakan sebagai contoh dari itu.

$$
\text { Selanjutnya Prahalad }
$$
menambahkan bahwa teknologi konvergen menyebabkan batas industri bergeser dan kabur, mengubah produk dan layanan secara alami. Mempertimbangkan lanskap kompetitif yang sedang berkembang yang dibawa dengan digitalisasi. Secara tradisional, pendidikan, komunikasi, rekreasi dan pasar hiburan semua dilayani oleh industri dan bisnis yang berbeda:industri elektronik konsumen (termasuk produk televisi dan audio / video);bisnis komputer (termasuk desktop, laptop dan konsol video). Pertahanan untuk melawan semakin boundaryless dan terusmenerus mengubah ruang kompetitif.

\section{SIMPULAN}

Secara ringkas evolusi pemikiran manajemen strategis dapat dilihat pada table 4

Tabel 4

Evolusi Pemikiran Manajemen Strategik Periode sebelum Tahun 2000an

\begin{tabular}{|c|c|c|c|c|c|}
\hline Periode & 1960an & 1970an & 1980an & 1990an & 2000 \\
\hline Label & Definisi Strategi & $\begin{array}{l}\text { Mengkonsepkan } \\
\text { manajemen } \\
\text { Strategic }\end{array}$ & $\begin{array}{l}\text { Paradigma } \\
\text { Industrial } \\
\text { Organization } \\
\text { Economic (IO) } \\
\text { dari strategi }\end{array}$ & $\begin{array}{l}\text { Pandangan } \\
\text { Berdasarkan } \\
\text { Sumberdaya } \\
\text { (RBV) dari } \\
\text { strategi }\end{array}$ & $\begin{array}{l}\text { Paradigma baru } \\
\text { pada manajemen } \\
\text { strategik }\end{array}$ \\
\hline $\begin{array}{l}\text { Beberapa Tokoh } \\
\text { yang Berpenga- } \\
\text { ruh }\end{array}$ & $\begin{array}{l}\text { Chandler (1962) } \\
\text { Ansoff (1965) } \\
\text { Learned et al } \\
(1965) \\
\text { Andrews (1971) }\end{array}$ & $\begin{array}{l}\text { Rumelt (1974) } \\
\text { Mintberg (1978) } \\
\text { Ansoff (1979) }\end{array}$ & $\begin{array}{l}\text { Porter (1980) } \\
\text { Porter (1986) }\end{array}$ & $\begin{array}{l}\text { Wernerfelt } \\
(1984) \\
\text { Barney (1991) } \\
\text { Prahalad dan } \\
\text { Hamel (1990) }\end{array}$ & $\begin{array}{l}\text { Nonaka (1991) } \\
\text { Hammel (2000) } \\
\text { Pfeffer dan } \\
\text { Suton (2000) }\end{array}$ \\
\hline Tema Dominan & $\begin{array}{l}\text { Corporate } \\
\text { strategy, } \\
\text { planning and } \\
\text { growth }\end{array}$ & $\begin{array}{l}\text { Strategy and } \\
\text { management } \\
\text { content and } \\
\text { process }\end{array}$ & $\begin{array}{l}\text { Competitive } \\
\text { advantage } \\
\text { development }\end{array}$ & $\begin{array}{l}\text { Resources and } \\
\text { capabilities } \\
\text { development }\end{array}$ & $\begin{array}{l}\text { Learning, } \\
\text { Knowledge and } \\
\text { Innovation }\end{array}$ \\
\hline
\end{tabular}




\begin{tabular}{|c|c|c|c|c|c|}
\hline Periode & 1960an & 1970an & 1980an & 1990an & 2000 \\
\hline Pemikiran & $\begin{array}{lr}\text { Stategi } & \text { sebagai } \\
\text { aturan } & \text { untuk } \\
\text { m e m b u a t } \\
\text { keputusan }\end{array}$ & $\begin{array}{l}\text { Mengevaluasi } \\
\text { dan mengimple- } \\
\text { me n t a s i ka n } \\
\text { aspek2 kritis } \\
\text { dari strategi yang } \\
\text { dirumuskan }\end{array}$ & $\begin{array}{l}\text { Menganalisis } \\
\text { lima kekuatan } \\
\text { dari ketertarikan } \\
\text { industry untuk } \\
\text { mengembangkan } \\
\text { k e u g g u lan } \\
\text { k o m e t i t if } \\
\text { melalui strategi } \\
\text { generik }\end{array}$ & $\begin{array}{l}\text { Sumber } \\
\text { keunggulan } \\
\text { kompetitif adalah } \\
\text { sumberdaya yang } \\
\text { valuable, rare, } \\
\text { inimitable, and } \\
\text { non-substitutable } \\
\text { (VRIN) }\end{array}$ & $\begin{array}{l}\text { Model strategis } \\
\text { dinamis dimana } \\
\text { perus a ha a n } \\
\text { mendapatkan } \\
\text { i n f o m a s i } \\
\text { b e r a r a }, \\
\text { menciptakan } \\
\text { pengetahuan dan } \\
\text { mengumpulkan } \\
\text { kemampuan tak } \\
\text { berwujud dalam } \\
\text { proses belajar }\end{array}$ \\
\hline \multirow{2}{*}{$\begin{array}{l}\text { Konsep strategi, } \\
\text { alat, dan teknik }\end{array}$} & $\mathrm{S} \quad \mathrm{W} \quad \mathrm{O} \quad \mathrm{T}$, & \multirow[t]{2}{*}{ Value Chain } & \multirow{2}{*}{$\begin{array}{l}5 \text { Forces Model } \\
\text { Strategic Choice }\end{array}$} & $\mathrm{C}$ & New Integrated \\
\hline & $\begin{array}{l}\text { Exp e ri e n c e } \\
\text { Curve, Growth } \\
\text { Matrix }\end{array}$ & & & $\begin{array}{l}\text { Com p e te n c e } \\
\text { Value } \quad \text { System, } \\
\text { VRIO, Game } \\
\text { Theory }\end{array}$ & $\begin{array}{l}\text { In formation } \\
\text { Technology } \\
\text { Systems }\end{array}$ \\
\hline
\end{tabular}

\section{DAFTAR PUSTAKA}

Barney, J. (1991). Firm Resources and Sustained Competitive Advantage. Journal of Management, 17(1), 99-120.

Bracker, J. (1980). The Historical Development of the Strategic Mnagement Concept. Academy of Management Review, 5(2), 219-224.

Davis, G. G. D. P. (1984). Porter's (1980) Generic Strategies as Determinants of Strategic Grou[ Membership and Organizational Performance. Academy of Management Journal, 27(3), 467488.

Gastón de los Reyes, J. (2011). 40 Years Later: What Happened To Andrews 'S. Harvard University Press. San Antonio: Academy of Management. https://doi. org/10.1007/s13132-014-0237-0

Godfrey, P., \& Hill, C. W. L. (1995). The Problem of Unobservables in Stratgeic Management Research. Strategic Management Journal, 16(2), 519-533.

Guillén, M., \& Mele, D. (2006). Intellectual Evolution of Strategic Management and its Relationship With Ethics and Social Responsibility. IESE Business School Working Paper ..., 3(658). Retrieved from http://papers.ssrn.com/sol3/papers. cfm?abstract_id $=960663$

Hoskisson, R. E., Hitt, M. A., Wan, W. P., \& Yiu, D.(1999). Theoryandresearchinstrategic management: Swings of a pendulum. Journal of Management. https://doi. org/10.1177/014920639902500307

Kuras, O. (2002). The Capacitive Resistivity Technique for Electrical Imaging of the Shallow Subsurface. (Ph.D Thesi). Nottingham:_eprints@nottingham. ac.uk.

Mburu, S. N., \& Thuo, J. K. (2015). Understanding the Concept of Strategic Intent. International Refereed Journal of Engineering and Science (IRJES), 4(6), 2319-183. Retrieved from www. irjes.com

Meyer, J. W., \& Rowan, B. (1977). Institutionalized Organizations: Formal Structure as Myth and Ceremony Institutionalized Organizations: Formal Structure as Myth and Ceremonyl. American Journal of Sociology, 83174254(132), 340-363. https://doi. org/10.1086/226550

Miles, R. E., Snow, C. C., Meyer, A. D., Coleman, H. J., Miles, R. E., \& Meyer, A. D. (1978). Organizational Strategy 
, Structure, and Process. Academy of Management Journal, 3(3), 546-562.

Mintzberg, H., Ahlstrand, B., \& Lampel, J. (1998). Strategy Safari. (A. of S. \& S. Inc., Ed.) (The Free P). New York.

Nonaka, I., \& Lewin, A. Y. (1994). Dynamic Theory Knowledge of Organizational Creation. Organization Science, 5(1), 14-37.

Pfeffer, Jeffrey and Sutton, R. I. (2000). The Knowing-Doing Gap: How Smart Companies Turn Knowledge into Action. Harvard University Press, (November), 256.

Porter, M. E. (1991). Toward A Dynamic Theory of Strategy. Strategic Management Journal, 12(2), 95-117.

Prahalad;, C. K. V. R. (2003). The New Frontier of Experience Innovation. Management Review, 44(4), 12-18.

Prahalad, G. H. C. . (1989). Strategic Intent. Havard Business Review, 700(November), 96-116. https://doi. org/10.1225/R0507N
Priem, R. L., \& Butler, J. E. (2001). Is The Resource-Based "View" A Useful Perspective For Strategic Managemen Research? Academy of Management Review, 26(1), 22-40.

Robert, M., \& Grant, R. M. (1991). The resource-based theory of competitive advantage: implications for strategy formulation. California Management Review, 33(3), 114-135.

Teece, D. J. (2007). Explicating Dynamic Capalilities: The Nature And Microfoundations of (Sustainable) Enterprise Performance. Strategic Management Journal, 28(2), 13191350. https://doi.org/10.1002/smj

Wernerfelt, B. (1984). A Resource-based View of the Firm. Strategic Management Journal, 5(2), 171-180.

Wilson, J. F., \& Toms, J. S. (2012). Revisiting Chandler on the theory of the firm. Handbook on the Economics and Theory of the Firm, 297-307. https:// doi.org/10.4337/9781848446489.00033 